\title{
Soil-Derived Microbial Consortia Enriched with Different Plant Biomass Reveal Distinct Players Acting in Lignocellulose Degradation
}

\author{
Maria Julia de Lima Brossi ${ }^{1}$ - Diego Javier Jiménez ${ }^{1}$ - Larisa Cortes-Tolalpa ${ }^{1}$. \\ Jan Dirk van Elsas ${ }^{1}$
}

Received: 5 June 2015 / Accepted: 27 September 2015 / Published online: 20 October 2015

(C) The Author(s) 2015. This article is published with open access at Springerlink.com

\begin{abstract}
Here, we investigated how different plant biomass, and - for one substrate - $\mathrm{pH}$, drive the composition of degrader microbial consortia. We bred such consortia from forest soil, incubated along nine aerobic sequential - batch enrichments with wheat straw (WS1, pH 7.2; WS2, pH 9.0), switchgrass (SG, $\mathrm{pH} 7.2$ ), and corn stover (CS, $\mathrm{pH} 7.2$ ) as carbon sources. Lignocellulosic compounds (lignin, cellulose and xylan) were best degraded in treatment SG, followed by CS, WS1 and WS2. In terms of composition, the consortia became relatively stable after transfers 4 to 6 , as evidenced by PCRDGGE profiles obtained from each consortium DNA. The final consortia differed by $\sim 40 \%$ (bacteria) and $\sim 60 \%$ (fungi) across treatments. A 'core' community represented by $5 / 16$ (bacteria) and 3/14 (fungi) bands was discerned, next to a variable part. The composition of the final microbial consortia was strongly driven by the substrate, as taxonomicallydiverse consortia appeared in the different substrate treatments, but not in the (WS) different $\mathrm{pH}$ one. Biodegradative strains affiliated to Sphingobacterium kitahiroshimense, Raoultella terrigena, Pseudomonas putida, Stenotrophomonas rhizophila (bacteria), Coniochaeta ligniaria and Acremonium sp. (fungi) were recovered in at least three treatments, whereas strains affiliated to Delftia
\end{abstract}

Electronic supplementary material The online version of this article (doi:10.1007/s00248-015-0683-7) contains supplementary material, which is available to authorized users.

Maria Julia de Lima Brossi

majubrossi@gmail.com

1 Department of Microbial Ecology, Groningen Institute for Evolutionary Life Sciences, University of Groningen, Nijenborgh 7, 9747AG Groningen, The Netherlands tsuruhatensis, Paenibacillus xylanexedens, Sanguibacter inulus and Comamonas jiangduensis were treatment-specific.

Keywords Plant biomass - Bioconversion · Bacterial-fungal consortia $\cdot($ Hemi) cellulolytic activity

\section{Introduction}

Wheat straw (WS), corn stover (CS), and switchgrass (SG) constitute excellent sources of lignocellulose with high potential for the production of useful compounds such as biofuel, polyolefin-based plastics and lactic acid. Lignocellulose is mainly composed of cellulose, hemicellulose, lignin and pectin [10,29]. Its composition in plant matter can vary according to plant type, and even within plant species [2], which affects its bioconversion $[14,15]$. Thus, one may surmise that WS, $\mathrm{CS}$, and SG substrates potentially require diverse specialized combinations of microorganisms for its deconstruction $[6,30$, $37,39]$. It is currently accepted that proper biodegradation of lignocellulosic substrates requires a complex set of enzymes. Thus, peroxidases, laccases, endoglucanases, exoglucanases, $\beta$-glucosidases, fucosidases and xylanases [28, 40, 42], among other enzymes, may be required in different and fluctuating amounts and proportions. Moreover, cultures from pure isolates have often demonstrated unsatisfactory biodegradation rates $[20,21]$. Hence, recent work has focused on plant biomass degradation by microbial consortia on the premise that the expected diversity of the microbially - secreted enzymes will result in efficient degradation rates [34]. The microbial groups involved may even be interdependent, with each one exerting distinct functions, the sum of which is synergistic for the process [23]. And, as a result, the microbial consortia may also better withstand physiological fluctuations. Examining the microbial consortia bred on lignocellulosic 
plant biomass is useful for (1) understanding (2) designing, and (3) testing superior biodegradative agents [43].

To produce such superior microbial consortia, the dilution-tostimulation approach, which uses sequential - batch enrichments on the same substrate, is indicated [16] as it allows to establish stable microbial consortia with desirable biodegradation properties $[5,18,27]$. Effective consortia can be readily derived from a source community from forest soil $[8,18]$. However, in the light of the richness of lignocellulose biodegradative capacities in forest soil, it is important to assess to what extent the choice of lignocellulosic substrates (e.g., WS, CS, or SG) directs the assembly of efficient degrading microbial consortia.

Here, we hypothesized that, given the overall similarity in substrate composition, microbial consortia with largely similar structures will be produced from one source community in a sequential batch dilution-to-stimulation approach. However, an alternative hypothesis postulates that such communities are bound to be different in the light of the - possibly subtledifferences in substrate composition. Following these two divergent lines of reasoning, the main objectives of this study were (1) to produce effective microbial consortia on the aforementioned three substrates and (2) to test whether these diverse substrates (next to variation in $\mathrm{pH}$ for the WS treatment) drive the establishment of different (or similar) microbial lignocellulose-degrading consortia.

\section{Materials and Methods}

\section{Plant Biomass Preparation}

We collected approximately $3 \mathrm{~kg}$ of each plant biomass-i.e., wheat straw, switchgrass and corn stover-in local farms in Groningen, The Netherlands. Each plant biomass raw material was transported to the laboratory $(<24 \mathrm{~h})$ at room temperature $\left(20^{\circ} \mathrm{C}\right)$ for further processing. The raw material was air-dried at $50{ }^{\circ} \mathrm{C}$ for $24 \mathrm{~h}$ before grinding using a hammer mill, yielding pieces $<1 \mathrm{~mm}$.

The experimental design encompassed three different treatments with respect to the plant biomass used (a proxy for different carbon sources), next to one (with WS), in which $\mathrm{pH}$ was varied as follows: wheat straw (WS1), switchgrass (SG), and corn stover (CS) - all maintained at $\mathrm{pH}$ 7.2, and wheat straw (WS2) under a pH 9.0. All treatments were performed in triplicate flasks $(n=3)$, and all flasks were kept under the same conditions along the whole experiment to avoid bias.

\section{Serial Batch Enrichment Cultures Using the Dilution-to-Stimulation Approach}

Ten randomly taken soil samples of $10 \mathrm{~g}$ were collected from a forest soil (0 to $10 \mathrm{~cm}$ depth) in Groningen, the Netherlands (53.41 N; 6.90 E) in September, 2013 (before leaf abscission).
These samples were mixed to produce one representative soil sample to be used as the source inoculum for all treatments. The soil sample was transported to the laboratory at room temperature $\left(20^{\circ} \mathrm{C}\right)$ for further processing $(<24 \mathrm{~h})$. Cell suspensions were prepared by adding $10 \mathrm{~g}$ of the mixed soil to an Erlenmeyer flask $(250 \mathrm{~mL})$ containing $10 \mathrm{~g}$ of sterile gravel in $90 \mathrm{~mL}$ of $0.9 \%$ saline $(\mathrm{NaCl})$. The flask was shaken for $20 \mathrm{~min}$ at $250 \mathrm{rpm}$, and $3 \mathrm{~mL}$ of cell suspension was then sampled and frozen $\left(-20^{\circ} \mathrm{C}\right)$ for total DNA extraction. Moreover, aliquots $(150 \mu \mathrm{L})$ of the cell suspension were added to triplicate flasks containing $15 \mathrm{~mL}$ of mineral salt medium (MSM), pH 7.2 for treatments WS1, SG, and CS and $\mathrm{pH} 9.0$ for treatment WS2, with $1 \%$ of the respective lignocellulosic substrates; all flasks were supplemented with $15 \mu \mathrm{L}$ of standard trace element and vitamin solution. For a detailed description of this method, see Jiménez et al. [18]. Subsequently, flasks were incubated at $28^{\circ} \mathrm{C}$ with shaking at $150 \mathrm{rpm}$. Two controls, i.e., one without substrate and one without microbial source (for all substrates) were also set up. Cultures were monitored for growth at regular times, and once the systems reached high cell density $\left(10^{7}-10^{8}\right.$ cells $\mathrm{mL}^{-1}$ ) (between 5 and 6 days), aliquots $(15 \mu \mathrm{L})$ were transferred to $15 \mathrm{~mL}$ of fresh medium (lignocellulose source in MSM supplemented with vitamins and trace elements) thus giving a dilution of $10^{-3}$. This procedure was repeated nine times, giving in total nine enrichments. Cell counts were obtained by microscopy using a Bürke-Turk chamber (Blaubrand ${ }^{\mathbb{B}}$ ) according to a standard protocol. The quantification was done directly after the transfer and at the end of growth in each transfer. The $\mathrm{pH}$ values of all treatments were regularly monitored and revealed to be largely stable along the incubation period.

Finally, samples were taken from the consortia, at the end of growth in each transfer, being one 2-mL aliquot (from each flask $-n=3$ ) for DNA extraction and another $1-\mathrm{mL}$ aliquot stored in glycerol $(25 \%)$ at $-80{ }^{\circ} \mathrm{C}$.

\section{Total DNA Extraction and Quantitative PCR}

DNA extractions from the consortia were performed using $2 \mathrm{~mL}$ of each sample. The UltraClean Microbial DNA Isolation kit (MoBio ${ }^{\circledR}$ Laboratories Inc., Carlsbad, USA) was used according to the manufacturer's instructions. Bacterial and fungal counts were obtained by quantifying, respectively, the bacterial $16 \mathrm{~S}$ rRNA gene (regions V5-V6) and the fungal first internal transcribed spacer (ITS1) region by quantitative PCR (qPCR) using $5 \mathrm{ng}$ of extracted consortial DNA as the template and the primer sets 16SFP/16SRP and 5.8S/ITS1 [31]. Standard curves were constructed using serial dilutions of plasmids ( 1 to $8 \log$ copies $\mu \mathrm{L}^{-1}$ ) that contained cloned bacterial 16S rRNA gene and ITS1 fragments from Serratia plymuthica (KF495530) and Coniochaeta ligniaria (KF285995), respectively. Absolute quantification was carried out in three replicates on an ABI Prism 7300 Cycler (Applied Biosystem, Lohne, Germany). The bacterial and fungal abundances in the different samples 
were expressed as target gene copy numbers per milliliter. Statistical comparisons between the means were performed using one-way ANOVA (Tukey's test).

\section{Substrate Weight Loss}

At the end of transfers 6 and 9, the residual solid matter in the cultures was washed and dried as described in Du et al. [11], after which the weight of the residual matter was measured and compared to a reference control treatment without the inoculum. The percentage of weight loss was defined as the ratio of the weight loss compared to the initial weight (\%) as calculated by the following formula:

Substrate weight loss $(\%)=[(a-b) / c] \times 100$; where: $a=$ residual control substrate weight; $b=$ residual substrate weight; $c=$ total substrate weight.

Statistical comparisons of the samples' substrate weight losses were performed using one-way ANOVA of the means per treatment (Tukey's test).

\section{Lignocellulosic Composition of Substrates and Degradation Rate}

In order to determine the composition of each substrate and the degradation rate of their lignocellulosic components, we used fourier transformed infrared (FTIR) spectroscopy [1]. To do so, for all used substrates (i.e., WS, SG, and CS), we quantified the percentages of lignin, cellulose and hemicellulose (i.e., xylan from birchwood as the proxy) content before and after incubation (transfer nine).

Prior to quantification, the material from the triplicates of each treatment (WS1, WS2, SG, and CS) was individually dried at $50{ }^{\circ} \mathrm{C}$ for $24 \mathrm{~h}$. Standard curves were determined using mixed components (i.e., lignin, cellulose and xylan) in eight different proportions (Table S1); this resulted in reference spectra and validation of the prediction of the lignocellulosic components. The compounds were measured using an FTIR spectrum machine (Thermo Fisher Scientific). The data were preprocessed using Savitzky-Golay differentiation (second derivative; polynomial order 2 and 31-point curve employed for each correction) in order to fit a polynomial regression to each successive curve segment. This generated smoothed curves [33], followed a standard normal variate (SNV) to transform centers and scales of each individual spectrum [9]. After preprocessing, spectrum analyses were conducted, creating a partial least squares regression model using the standard curve, including an FTIR wavelength from 800 to $1800 \mathrm{~cm}^{-1}[12,22]$. The predictive model displayed $R^{2}$ values of $0.95,0.96$ and 0.97 for lignin, cellulose and hemicellulose, respectively. All quantitative values are expressed in percentages of each compound (lignin, hemicellulose, and cellulose) presented in each substrate. Data analyses were performed using the "Unscrambler" software (CAMO Software, 2011).
Finally, degradation rates were determined, expressed as the ratio of the percentage of each component in the substrate after incubation compared to that before incubation as follows:

Degradation rate $(\%)=[(a-b) / a] \times 100$; where $a=$ percentage of component in the substrate before incubation and $b=$ percentage of component in the substrate after incubation.

Statistical comparisons of the mean' degradation rates were performed using one-way ANOVA (Tukey's test).

\section{PCR-DGGE analysis}

Bacterial and fungal community structures were assessed by PCR-denaturing gradient gel electrophoresis (PCR-DGGE) of the total consortium DNA along transfers 1, 4, 6 and 9 (T1, T4, T6, and T9) in all treatments. Thus, PCR-DGGE enabled the evaluation of consortial development and stability during the enrichment process as well as the identification shifts among the final consortium profiles. The microbial consortia were considered to be stable when the community structures (for bacteria or fungi) presented a similar pattern along at least three sequential transfers. In order to provide taxonomic information of specific bands found in our DGGE patterns, we performed a co-migration analysis. Briefly, 16S rRNA gene sequences were amplified for key selected consortium strains (see later) using DGGE primers, after which the resulting amplicons were run in parallel with the consortium amplicons. Bands that co-migrated with consortium bands were considered to presumptively identify organisms in the consortium patterns.

DGGE was performed in the Ingeny Phor-U System (Ingeny International, Goes, The Netherlands). PCR was performed with primers F968-GC clamp and R1401.1b for the bacterial 16S rRNA gene. For fungal communities, primers EF4/ITS4 were used in the first PCR, which was followed by a second amplification with the primers ITS1f-GC/ITS2. Primer sequences, PCR mixtures and cycling conditions were used as previously described [31]. The DGGE was performed in $6 \%(w / v)$ polyacrylamide gels with $45-65$ and $20-50 \%$ denaturant gradients for bacterial and fungal communities, respectively ( $100 \%$ is defined as $7 \mathrm{M}$ urea with $40 \%$ deionized formamide). Electrophoresis was carried out at $100 \mathrm{~V}$ for $16 \mathrm{~h}$ at $60{ }^{\circ} \mathrm{C}$, and the gels were stained for $30 \mathrm{~min}$ in $0.5 \% \mathrm{TAE}$ buffer with SYBR gold (final concentration of $0.5 \mu \mathrm{g} \mathrm{L}^{-1}$ ) (Invitrogen, Breda, The Netherlands). Images were taken using Imagemaster VDS (Amersham Biosciences, Buckinghamshire, UK). Fingerprinting results were analyzed using the GelCompar software (Applied Maths, Sint- Martens Latem, Belgium). The quantity of bands for each treatment was considered as a proxy roughly reporting on phylotype richness. We avoided quantifying band intensities since it may introduce bias into the analyses according to differences obtained in DNA templates and/or PCR efficiencies. Thus, presence/absence of band patterns were converted to Jaccard dissimilarity matrices 
for non-metric multidimensional scaling (nMDS) followed by the analysis of similarities (ANOSIM) statistical analysis using Primer6 (PrimerE, Ivybridge, UK). The global $R$ values, generated by ANOSIM, can range from -1 to 1 ; objects that are more dissimilar between groups than within groups are indicated by an $R$ greater than 0 ; an $R$ value of 0 indicates that the null hypothesis of no difference is true [13].

\section{Isolation and Identification of Bacterial and Fungal Strains}

Bacterial and fungal isolates were obtained from transfer 9 of all treatments on R2A agar (BD Difco ${ }^{\circledR}$, Detroit, USA) and potato dextrose agar (PDA) (Duchefa Biochemie BV, Haarlem, the Netherlands), respectively. Serial dilutions were performed in MSM, and $100 \mu \mathrm{L}$ of dilutions $10^{-5}$ to $10^{-8}$ were spread on the surface of each medium. Bacterial and fungal colonies with different morphologies were subsequently subcultured (aerobically) to purity. Totals of 11, 8, 9 and 8 bacterial and 4, 3, 3 and 3 fungal strains were thus isolated from treatments WS1, WS2, SC and CS, respectively. Bacterial isolates were preserved at $4{ }^{\circ} \mathrm{C}$ (on solid R2A medium) and $-80{ }^{\circ} \mathrm{C}$ (liquid R2A medium in glycerol $25 \%$ ), while fungal ones were cut from the solid medium $\left(25 \mathrm{~mm}^{2}\right.$ squares), after which they were preserved in distilled water at room temperature (Castellani method). The UltraClean Microbial DNA Isolation kit (MoBio ${ }^{\circledR}$ Laboratories Inc., Carlsbad, USA) was used according to the manufacturer's instructions for genomic DNA extractions. The bacterial $16 \mathrm{~S}$ rRNA genes were PCR amplified using $5 \mathrm{ng}$ of DNA and primers B8F and 1406R according to Taketani et al. [38]. For fungal strains, we amplified the partial $18 \mathrm{~S}$ rRNA gene using primers EF4 and ITS4 according to Jiménez et al. [18]. PCR products were sequenced by Sanger technology (LGC Genomics, Germany) using the 1406R primer (for bacteria) and ITS4 primer (for fungi). All resulting chromatograms were analyzed for quality using the Lucy algorithm (RDP website; http://rdp.cme.msu.edu/). In this, quality trimming by removing bases with low scores was applied. The level of minimum requirement was 400 bp with quality above 20 (phred score-one error per 100 bases read). Taxonomic assignment of the sequences was done using BLAST-N against the National Center for Biotechnology Information (NCBI) database (http://blast.ncbi.nlm.nih.gov/Blast.cgi). Sequences are publicly available in the GenBank database under accession numbers KR935800 to KR935847.

\section{Screening of Strains for (Hemi)cellulolytic Activity}

Screenings for (hemi)cellulolytic activity were done in mineral medium agar (MMA) $\left(0.2 \% \mathrm{NaNO}_{3} ; 0.1 \% \mathrm{~K}_{2} \mathrm{HPO}_{4}\right.$; $0.05 \% \mathrm{MgSO}_{4} ; 0.05 \% \mathrm{KCl} ; 1 \%$ of vitamin solution; $1.5 \%$ agar). We evaluated the growth (negative, weak and positive) of the strains in the presence of $0.2 \%$ glucose (positive control), $0.2 \%$ carboxymethyl cellulose (CMC; SigmaAldrich) to analyze cellulase activity and $0.2 \%$ xylan from beechwood (Sigma-Aldrich) to analyze hemicellulase (xylanase) activity. A drop (15 $\mu \mathrm{L})$ of bacterial culture grown overnight $\left(100 \mathrm{rpm}\right.$ at $25^{\circ} \mathrm{C}$ ) was introduced on to agar plate. Fungal strains (agar plugs of $25 \mathrm{~mm}^{2}$ ) were placed in the center of the agar plate. All assays were performed in duplicate using as a negative control MMA without a carbon source. The plates were incubated at $28^{\circ} \mathrm{C}$ for $36 \mathrm{~h}$ and, after evaluation of growth, they were flooded with Gram iodine [19] for the detection of CMC-ase and xylanase activity. We screened a total of 36 bacterial and 13 fungal strains. CMC and xylan degradation was indicated by detection of clearing zones (haloes) around the colonies. A cut-off value of more than $2.0 \mathrm{~mm}$ was considered as a positive result.

\section{Results}

\section{Bacterial and Fungal Abundances Along the Sequential Batch Transfers}

In all batches of all treatments, the initial population sizes revolved around $\sim 10^{5}$ bacterial cells $\mathrm{mL}^{-1}$, and these increased to $\sim 10^{8}$ bacterial cells $\mathrm{mL}^{-1}$ during incubation. Invariably, the cell densities increased rapidly to $\sim 10^{7}$ to $\sim 10^{8}$ over the first 3 days of incubation, indicating the occurrence of a phase of rapid growth, which was followed by a slower increase to the final cell densities. This pattern was consistently observed across treatments and transfers. No growth was observed in the control treatments (i.e., no substrate with inoculum and no inoculum with substrates). Overall, the qPCR measurements revealed the copy numbers of the bacterial $16 \mathrm{~S}$ rRNA gene to vary from $5.05 \pm 1.17 \times$ $10^{8} \mathrm{~mL}^{-1}$ (CS) $($ mean $\pm \mathrm{SD})$ to $9.22 \pm 0.21 \times 10^{8} \mathrm{~mL}^{-1}$ (WS1) after growth, whereas these were 1000-fold lower at the onset of each growth step. Thus, for all treatments, the bacterial densities reached rather similar maximum levels from similar initial levels (Fig. 1a). In contrast, the abundances of fungal propagules (after growth at each step) showed larger variation across transfers and treatments ranging from $6.94 \pm 3.84 \times 10^{5}$ (WS2) to $8.18 \pm 5.30 \times 10^{7}$ ITS1 copies $\mathrm{mL}^{-1}$ (WS1) (Fig. 1b). Remarkably, significantly higher numbers of fungal propagules were observed in the WS than in the SG and CS samples (ANOVA, $p<0.05$ ).

\section{Substrate Weight Loss}

We evaluated substrate weight loss after microbial consortium development on the different plant biomass along transfers 6 (T6) and 9 (T9) through gravimetric determination of dry substrate. Following T6, substrate weight losses were minimally 


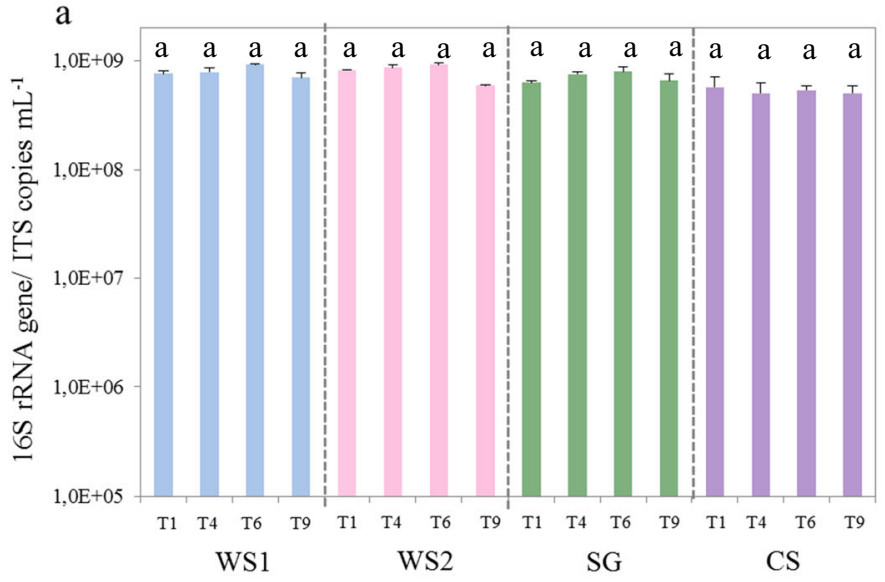

Fig. 1 Copy numbers ( $y$ axis) of (a) bacterial 16S rRNA gene and (b) fungal ITS region across transfers 1, 4, 6 and 9 for all treatments. Transfers and treatments are indicated on the $x$ axis. Error bars represent the standard deviation of the means of three independent replicates. Different lowercase letters (a) refer to differences among the 16S rRNA gene abundances

$36.05 \pm 0.04 \%$ (WS2) and maximally $42.06 \pm 0.06 \%$ (CS). These increased significantly at T9 when values of $42.04 \pm 0.06 \%$ (WS2, minimum) and $48.04 \pm 0.04 \%$ (CS, maximum) were found. The values were significantly different (ANOVA, $p<0.01$, Fig. 2).

\section{Lignocellulosic Composition of WS, CS and SG Substrates and Degradation Rate}

The composition of all plant matter in terms of lignin, cellulose and hemicellulose (xylan) was measured for all substrates. Moreover, we measured these parameters before and after consortial growth in transfer 9, allowing calculation of the degradation rate of these components (Table 1; Fig. 3). WS, CS and SG differed within limits with respect to the presence of the

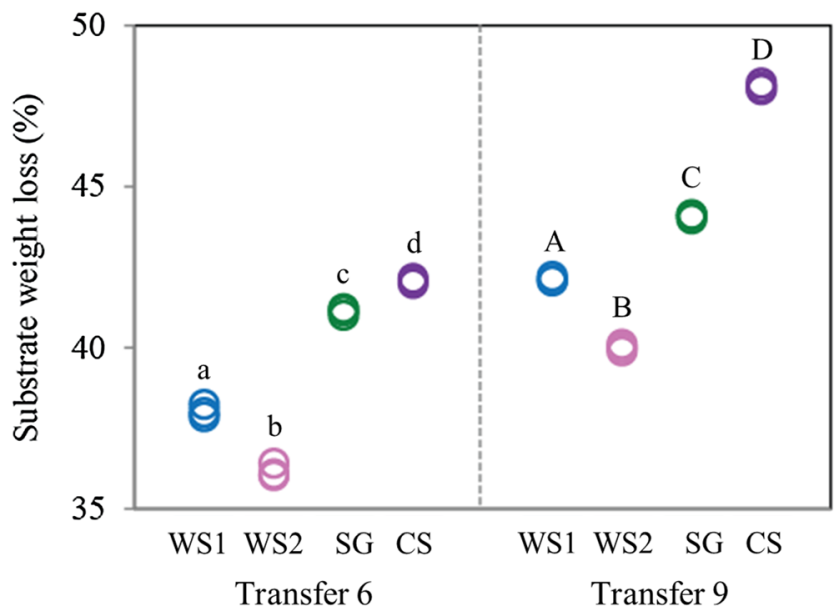

Fig. 2 Substrate weight loss (\%) of different substrates in the transfers 6 and 9. Different lowercase letters $(a-d)$ refer to differences among treatments in T6 and uppercase ones $(A-D)$ to differences among treatments, at T9 (ANOVA, $p<0.01$ ). Abbreviations: WS1 - wheat straw pH 7.2, WS2 - wheat straw pH 9.0, $S G$ - switchgrass pH 7.2, $C S$ - corn stover $\mathrm{pH} 7.2$

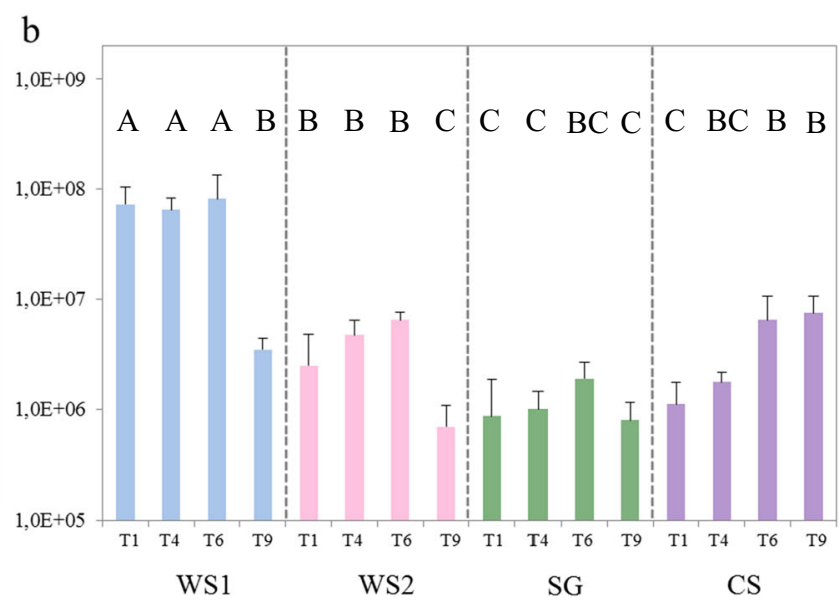

within treatments and uppercase letters $(A-C)$ to differences among ITS1 region abundances across treatments (ANOVA, $p<0.05$ ). Abbreviations: WS1 - wheat straw $\mathrm{pH} 7.2$, WS2 - wheat straw $\mathrm{pH} 9.0, S G$ - switchgrass $\mathrm{pH}$ 7.2, $C S$ - corn stover $\mathrm{pH} 7.2$

main measured components lignin, cellulose, and hemicellulose (Table 1). In terms of degradation by the T9 consortium, we found the highest lignin degradation rate in treatment SG $(39.32 \pm 4.04 \%)$, whereas the highest degradation rate of cellulose occurred in treatment WS1 (51.92 $\pm 0.41 \%)$ and of hemicellulose in CS $(62.79 \pm 4.69 \%)$. Moreover, considering the total degradation of lignocellulosic components (i.e., lignin+ cellulose+xylan), SG turned out to be the most efficiently degraded substrate $(47.67 \pm 2.33 \%)$, followed by CS $(43.81 \pm$

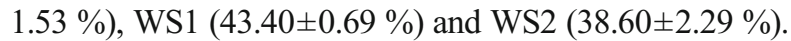

\section{Analysis of Microbial Consortium Structures by PCR-DGGE}

Using total consortium DNA, bacterial 16S rRNA gene and ITS region-based PCR-DGGE analyses were used to evaluate

Table 1 Lignocellulosic composition (lignin, cellulose, and hemicellulose) of substrates*

\begin{tabular}{llll}
\hline Substrate & Lignin (\%) & Cellulose (\%) & Hemicellulose (\%) \\
\hline $\mathrm{WS}^{\mathrm{a}}$ & $22.2 \pm 0.8$ & $45.5 \pm 1.3$ & $31.3 \pm 0.9$ \\
$\mathrm{WS}^{\mathrm{b}}$ & $18.0 \pm 1.0$ & $21.9 \pm 0.6$ & $16.1 \pm 0.7$ \\
$\mathrm{WS}^{\mathrm{b}}$ & $18.4 \pm 0.5$ & $24.2 \pm 0.8$ & $18.1 \pm 1.6$ \\
$\mathrm{SG}^{\mathrm{a}}$ & $22.3 \pm 0.9$ & $45.9 \pm 1.5$ & $24.0 \pm 1.0$ \\
$\mathrm{SG}^{\mathrm{b}}$ & $13.5 \pm 1.0$ & $23.8 \pm 1.0$ & $10.9 \pm 1.1$ \\
$\mathrm{CS}^{\mathrm{a}}$ & $25.2 \pm 0.8$ & $40.3 \pm 1.7$ & $30.3 \pm 0.2$ \\
$\mathrm{CS}^{\mathrm{b}}$ & $17.4 \pm 0.6$ & $25.2 \pm 0.3$ & $11.2 \pm 1.0$ \\
\hline
\end{tabular}

Abbreviations: WS1 - wheat straw pH 7.2, WS2 - wheat straw pH 9.0, $S G$ - switchgrass $\mathrm{pH}$ 7.2, $C S$ - corn stover $\mathrm{pH} 7.2$

${ }^{\text {a }}$ Substrate before incubation

${ }^{\mathrm{b}}$ Substrate after incubation

*Average and standard deviation of three replicates 
Fig. 3 Degradation rates of lignocellulosic components of substrates in transfer 9. Different letters $(a-d)$ refer to differences among the means of treatments (ANOVA, $p<0.01$ ).

Abbreviations: $L$ - lignin, $C$ - cellulose, $H$ - hemicellulose, WS1 - wheat straw $\mathrm{pH} 7.2$, WS2 - wheat straw $\mathrm{pH} 9.0$, $S G$ - switchgrass $\mathrm{pH} 7.2$, CS - corn stover $\mathrm{pH} 7.2$

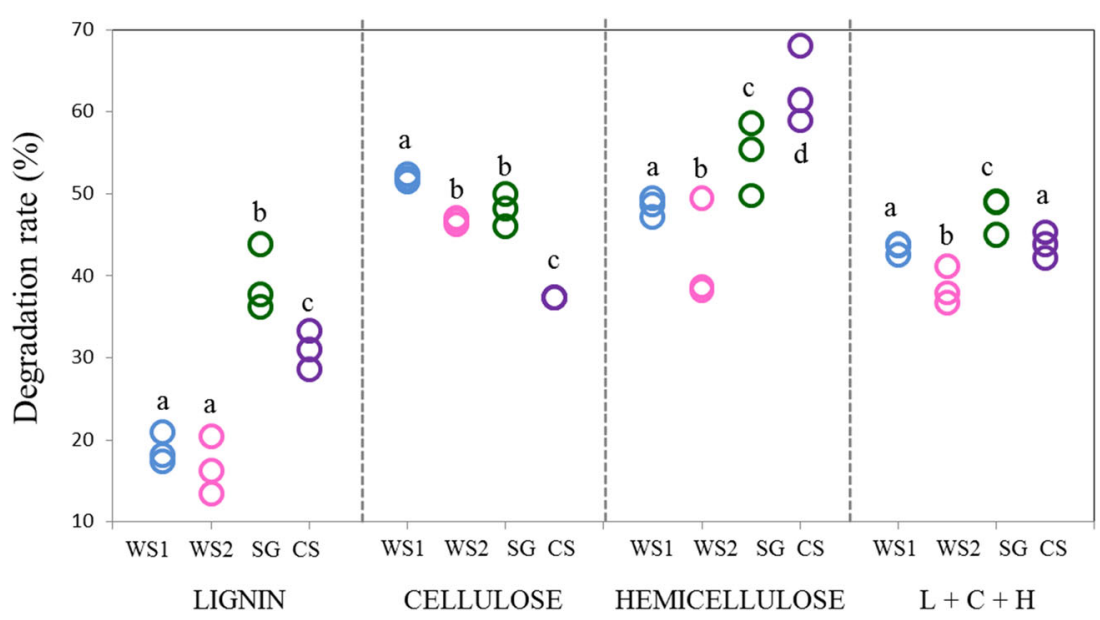

the evolution of the community structures across the sequential batches per treatment (Figs. 3 and 4). The source inoculum contained a "cloud" of bands, estimated to encompass at least 60 bands in the bacterial fingerprints and $>45$ bands in the fungal ones. The data further showed that the triplicates of each treatment in each transfer consistently depicted similar communities per treatment, with reduced richness as compared to the source inoculum. This was true for both the bacterial and fungal communities.

For treatments WS1, WS2 and CS, the bacterial community fingerprints showed highest numbers of bands (here taken as proxies for the richness of dominant organisms) in the initial transfer, with decreases afterwards (from initially 13, 13 and 11 to finally 10, 11 and 8 bands, respectively) (Fig. 4 (a, b, d)). On the other hand, band numbers increased in the SG consortia from initially 8 to finally 13 bands along the transfers (Fig. 4 (c)). Stability in the community compositions was observed after transfer 6 in WS1, SG and CS and after transfer 4 in WS2 (Fig. 4 (A-D)).

Fungal richness revealed a trend that was similar to that observed for bacterial richness along the transfers. In transfer 1, WS1, WS2, SG and CS showed 23, 23, 10 and 15 bands
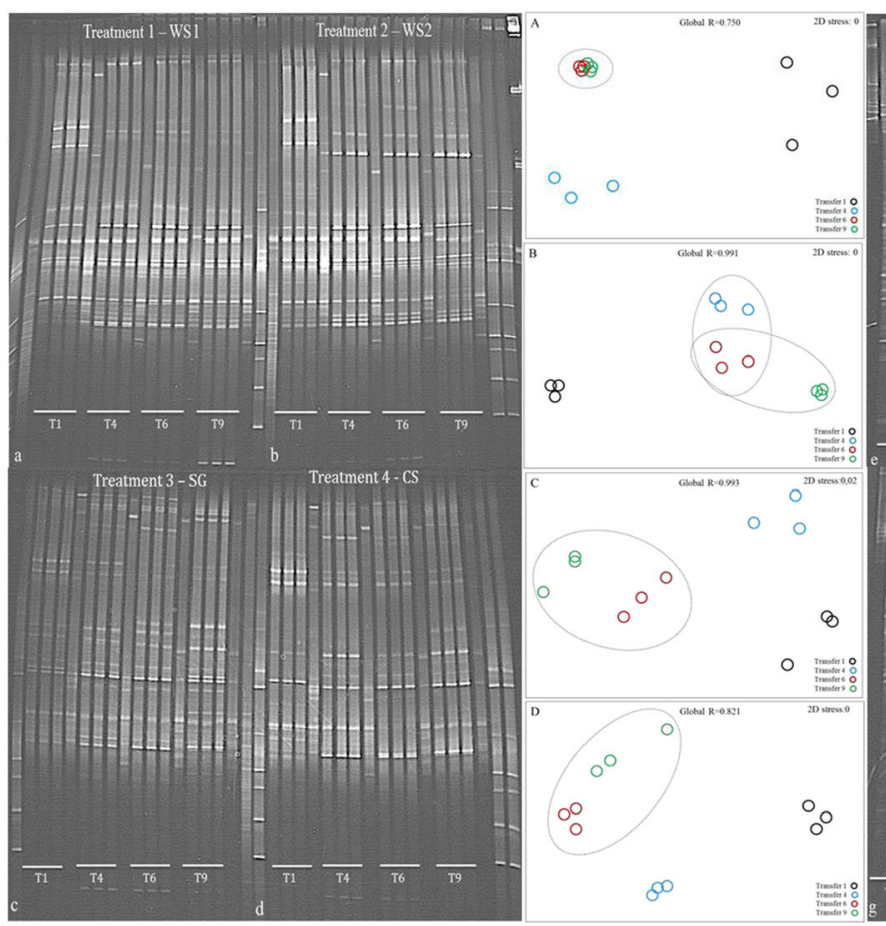

Fig. 4 Community fingerprints (PCR-DGGE) of bacterial and fungal communities along transfers $1,4,6$ and 9 on different substrates; $(a)$ $\mathrm{WS} 1,(b) \mathrm{WS} 2,(c) \mathrm{SG}$ and $(d) \mathrm{CS}$, for bacterial communities and (e) WS1, $(f) \mathrm{WS} 2,(g) \mathrm{SG}$ and $(h) \mathrm{CS}$, for fungal communities. $A, B, C$ and $D$ represent nMDS and statistical analyses (ANOSIM; global $R$

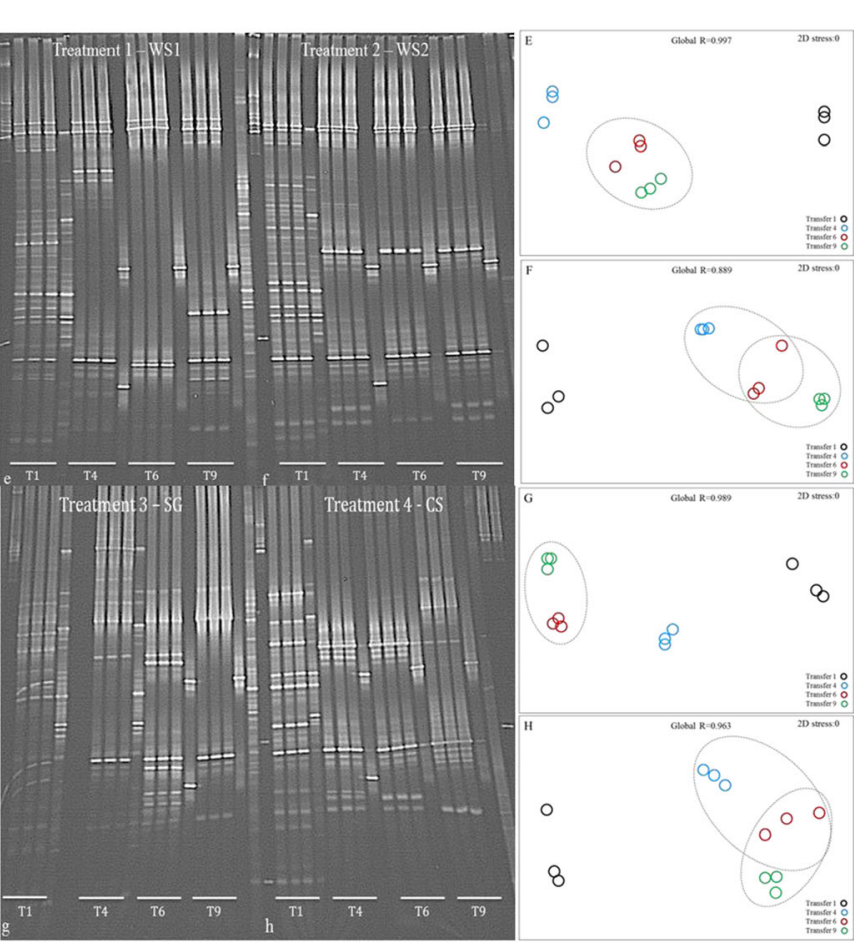

value) for bacterial communities in the different substrates and $\mathbf{E}, \mathbf{F}, \mathbf{G}$ and $\mathbf{H}$ for fungal communities in the different substrates. Abbreviations: WS1 - wheat straw pH 7.2, WS2 - wheat straw pH 9.0, SG - switchgrass $\mathrm{pH} 7.2, C S$ - corn stover $\mathrm{pH} 7.2$ 
respectively, which declined to respectively $7,6,5$ and 7 bands in transfer 9. This trend was consistent across the replicates (Fig. $4(\mathrm{e}-\mathrm{h}))$. The fungal community structures reached stability after transfer 6 in WS1 and SG and after transfer 4 for WS2 and CS (Fig. 4 (E-H)).

The T9 PCR-DGGE profiles were then compared across the treatments (Fig. 5). Cluster analysis of these profiles revealed $\sim 40$ and $\sim 60 \%$ of differences across treatments for the bacterial and fungal consortia, respectively (Supplementary Fig. S1). Clearly, substrate type, next to $\mathrm{pH}$ for the treatments using WS, drove the bacterial community structures (Fig. 5 (A)), these being partially variable and partially stable. Thus, a common core, consisting of five bands, was observed across all treatments (i.e., B1, B5, B6, B7 and B8; Fig. 4 (a)). Next to this core, another band was found to be common between treatments WS1 and WS2 (B3; Fig. 5 (a)) and yet another one between treatments SG and CS (B4; Fig. 5 (a)). Using co-migration analyses, we found that the core consortium bands B1, B5, B6, B7 and B8 were similar to those from the strains (see later) affiliated with Sphingobacterium kitahiroshimense, Enterobacter amnigenus, Raoultella terrigena, Pseudomonas putida and Stenotrophomonas rhizophila, respectively (Fig. 5 (a)). Band B2 was assigned to Paenibacillus xylanexedens, which was only present in the SG consortium.

With respect to the fungal communities, substrate type also was a main factor driving the community structures. Treatments WS1 and WS2, which used the same substrate (wheat straw) under different $\mathrm{pH}$ values, incited similar fungal community structures (Fig. 5 (B)). Three common bands, potentially reflecting the existence of a fungal core community, were observed in the final consortia across all treatments (F3, F4 and F5; Fig. 5 (b)) next to a common one for treatments WS1 and WS2 (F1; Fig. 5 (b)) and another one for treatments SG and CS (F2; Fig. 5 (b)).

\section{Isolation of Bacterial and Fungal Strains from Enriched Cultures}

Totals of 36 bacterial and 13 fungal strains recovered from each treatment (Supplementary Fig. S2a, S2b) at T9 were presumptively identified by $16 \mathrm{~S}$ rRNA gene (bacteria) and ITS1 (fungi) sequencing (Table 2). Specifically, 11, 8, 9 and 8 bacterial and 4, 3, 3 and 3 fungal isolates recovered from WS1, WS2, SG and CS respectively, were thus identified.

The bacterial strains obtained from WS1 were affiliated ( $>99 \%$ identity with NCBI database entries; number of strains indicated between parentheses) with $R$. terrigena (3), $S$. kitahiroshimense (3), K. terrigena (1), P. putida (2), $S$. rhizophila (1), and E. amnigenus (1). Strains from WS2 were affiliated with Pseudomonas putida (2), R. terrigena (2), S. kitahiroshimense (2), and S. rhizophila (2). Treatment SG yielded strains affiliated with $S$. kitahiroshimense (2), $R$. terrigena (2), E. amnigenus (3), P. xylanexedens (1), and D. tsuruhatensis (1). Strains obtained from treatment CS were affiliated with S. rhizophila (2), S. kitahiroshimense (2), P. putida (1), C. jiangduensis (1), and S. inulinus (2). The isolated fungal strains for all treatments were affiliated (>95\% identity with NCBI database entries) with C. ligniaria and Acremonium sp. (Table 2; Fig. 6).

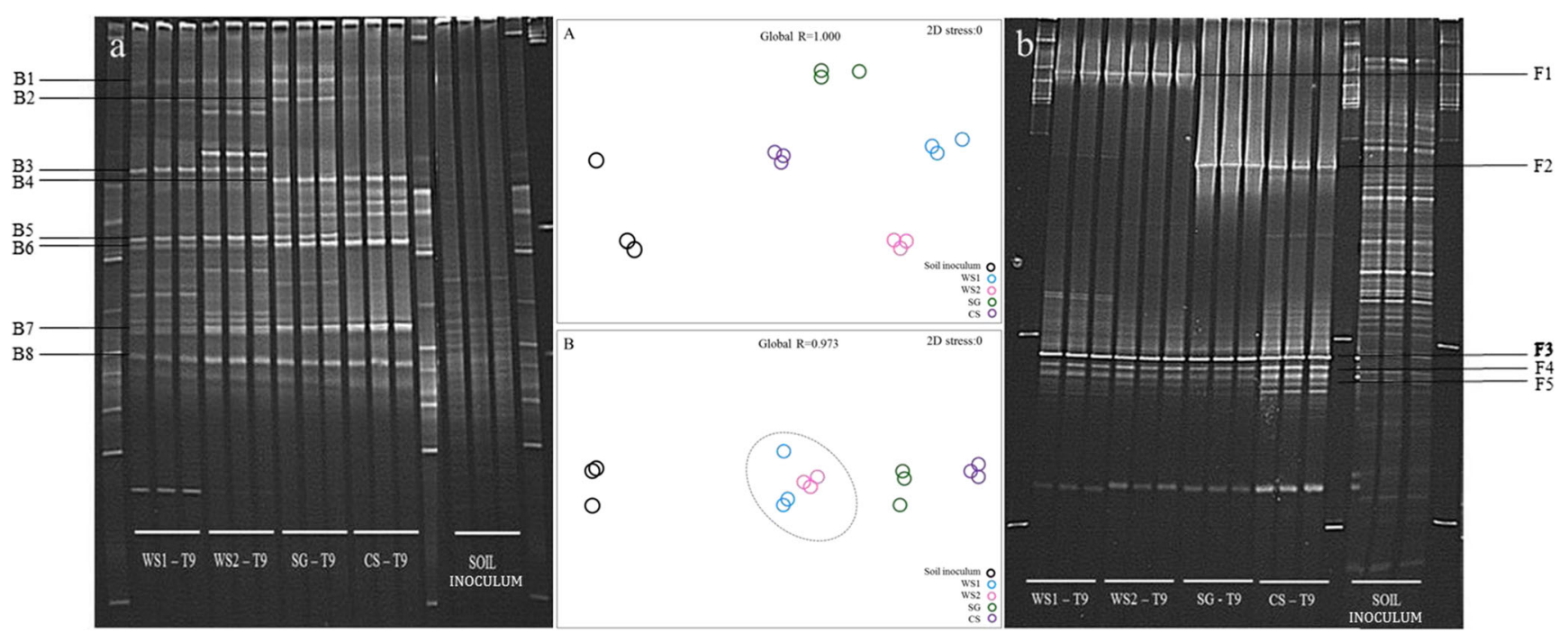

Fig. 5 Community fingerprinting (PCR-DGGE) for $(a)$ bacterial and $(b)$ fungal communities in the final consortia on different substrates and for the original soil inoculum. $A$ and $B$ represent nMDS and statistical analyses (ANOSIM; global $R$ value) for bacterial and fungal communities respectively. To details about B1 - B8 and F1 - F5, see text. Abbreviations: WS1 - wheat straw pH 7.2, WS2 - wheat straw $\mathrm{pH}$ 9.0, SG - switchgrass $\mathrm{pH} 7.2, C S$ - corn stover $\mathrm{pH} 7.2 \mathrm{~T}$ - transfer 9 
Table 2 Taxonomic affiliation and enzymatic activity of bacterial and fungal isolates from transfers 9 of all treatments

\begin{tabular}{|c|c|c|c|c|c|c|}
\hline $\mathrm{T}$ & Isol & Identification & Cov & Ident & Access no. & Enz ac \\
\hline \multicolumn{7}{|l|}{ Bacteria } \\
\hline \multirow[t]{11}{*}{ WS1 } & 1 & Raoultella terrigena $\mathrm{Rsh} 21$ 16S ribosomal RNA gene & $100 \%$ & $100 \%$ & KF796627.1 & $\mathrm{x}$ \\
\hline & 2 & Sphingobacterium mizutani $\mathrm{Ht} 8-22$ 16S ribosomal RNA gene & $99 \%$ & $99 \%$ & JF899285.1 & - \\
\hline & 3 & Raoultella terrigena PSB15 16S ribosomal RNA gene & $100 \%$ & $99 \%$ & HQ242728.1 & $\mathrm{x}$ \\
\hline & 4 & Klebsiella terrigena $16 \mathrm{~S}$ ribossonal RNA gene SW4 partial & $100 \%$ & $99 \%$ & Y17670.1 & $\mathrm{x}$ \\
\hline & 5 & Sphingobacterium mizutani $\mathrm{Ht} 8-22$ 16S ribosomal RNA gene & $100 \%$ & $99 \%$ & JF899285.1 & - \\
\hline & 6 & Sphingobacterium mizutani $\mathrm{Ht} 8-22$ 16S ribosomal RNA gene & $99 \%$ & $99 \%$ & JF899285.1 & - \\
\hline & 7 & Pseudomonas putida ATCC 17494 16S ribosomal RNA gene & $100 \%$ & $100 \%$ & AF094740.2 & - \\
\hline & 8 & Pseudomonas putida 214-D 16S ribosomal RNA gene, partial sequence & $100 \%$ & $100 \%$ & EF615008.1 & - \\
\hline & 9 & Stenotrophomonas rhizophila BG9 16S ribosomal RNA gene & $100 \%$ & $100 \%$ & KJ997741.1 & $\mathrm{x}$ \\
\hline & 10 & Raoultella terrigena PSB15 16S ribosomal RNA gene & $100 \%$ & $99 \%$ & HQ242728.1 & $\mathrm{x}$ \\
\hline & 11 & Enterobacter amnigenus h-14 16S ribosomal RNA gene & $100 \%$ & $100 \%$ & KC139434.1 & - \\
\hline \multirow[t]{8}{*}{ WS2 } & 12 & Pseudomonas putida 214-D 16S ribosomal RNA gene, partial sequence & $100 \%$ & $100 \%$ & EF615008.1 & - \\
\hline & 13 & Raoultella terrigena PSB15 16S ribosomal RNA gene & $100 \%$ & $100 \%$ & HQ242728.1 & $\mathrm{x}$ \\
\hline & 14 & Sphingobacterium kitahiroshimense 10C 16S ribosomal RNA gene & $100 \%$ & $99 \%$ & NR_041636.1 & $\mathrm{x}$ \\
\hline & 15 & Pseudomonas vranovensis IBFC2012-27 16S ribosomal RNA gene & $100 \%$ & $99 \%$ & KC246044.1 & $\mathrm{x}$ \\
\hline & 16 & Stenotrophomonas rhizophila BG9 16S ribosomal RNA gene & $100 \%$ & $100 \%$ & KJ997741.1 & $\mathrm{x}$ \\
\hline & 17 & Raoultella terrigena $\mathrm{RN} 16$ 16S ribosomal RNA gene & $100 \%$ & $100 \%$ & KC790281.1 & - \\
\hline & 18 & Sphingobacterium kitahiroshimense 10C 16S ribosomal RNA gene & $100 \%$ & $99 \%$ & NR_041636.1 & $\mathrm{x}$ \\
\hline & 19 & Stenotrophomonas rhizophila BG9 16S ribosomal RNA gene & $100 \%$ & $100 \%$ & KJ997741.1 & $\mathrm{x}$ \\
\hline \multirow[t]{9}{*}{ SG } & 20 & Sphingobacterium kitahiroshimense 10C 16S ribosomal RNA gene & $100 \%$ & $99 \%$ & NR_041636.1 & $\mathrm{x}$ \\
\hline & 21 & Sphingobacterium kitahiroshimense 10C 16S ribosomal RNA gene & $100 \%$ & $99 \%$ & NR_041636.1 & $\mathrm{x}$ \\
\hline & 22 & Raoultella terrigena Rsh21 16S ribosomal RNA gene & $100 \%$ & $99 \%$ & KF796627.1 & $\mathrm{x}$ \\
\hline & 23 & Raoultella terrigena Rsh21 16S ribosomal RNA gene & $100 \%$ & $99 \%$ & KF796627.1 & $\mathrm{x}$ \\
\hline & 24 & Enterobacter amnigenus h-14 16S ribosomal RNA gene & $100 \%$ & $100 \%$ & KC139434.1 & - \\
\hline & 25 & Enterobacter amnigenus h-14 16S ribosomal RNA gene & $100 \%$ & $100 \%$ & KC139434.1 & - \\
\hline & 26 & Paenibacillus xylanexedens JDG191 16S ribosomal RNA gene & $82 \%$ & $99 \%$ & JX035957.1 & $\mathrm{x}$ \\
\hline & 27 & Delftia tsuruhatensis LAM 29 16S ribosomal RNA gene & $100 \%$ & $99 \%$ & EU019989.1 & - \\
\hline & 28 & Enterobacter amnigenus h-14 16S ribosomal RNA gene & $100 \%$ & $100 \%$ & KC139434.1 & - \\
\hline \multirow[t]{8}{*}{ CS } & 29 & Sanguibacter inulinus $16 \mathrm{~S}$ ribosomal RNA: ST50 clone: NTS14 & $99 \%$ & $100 \%$ & AB920571.1 & $\mathrm{x}$ \\
\hline & 30 & Sphingobacterium faecium Gen5 16S ribosomal RNA gene & $100 \%$ & $99 \%$ & KJ726588.1 & - \\
\hline & 31 & Stenotrophomonas rhizophila BG9 16S ribosomal RNA gene & $100 \%$ & $100 \%$ & KJ997741.1 & $\mathrm{x}$ \\
\hline & 32 & Sphingobacterium anhuiense CW 186 16S ribosomal RNA gene & $100 \%$ & $99 \%$ & NR_044477.1 & - \\
\hline & 33 & Sanguibacter inulinus $16 \mathrm{~S}$ ribosomal RNA: ST50 clone: NTS14 & $100 \%$ & $100 \%$ & AB920571.1 & $\mathrm{x}$ \\
\hline & 34 & Pseudomonas alkylphenolia KL28, complete genome & $100 \%$ & $99 \%$ & СР009048.1 & - \\
\hline & 35 & Stenotrophomonas rhizophila BG9 16S ribosomal RNA gene & $100 \%$ & $100 \%$ & KJ997741.1 & $\mathrm{x}$ \\
\hline & 36 & Comamonas jiangduensis Amp3 16S ribosomal RNA gene & $100 \%$ & $99 \%$ & KJ726553.1 & $\mathrm{x}$ \\
\hline \multicolumn{7}{|l|}{ Fungi } \\
\hline \multirow[t]{4}{*}{ WS1 } & 1 & Coniochaeta ligniaria $2 \mathrm{w} 1 \mathrm{~F} 18 \mathrm{~S}$ ribosomal RNA gene & $93 \%$ & $99 \%$ & KF285992.1 & $\mathrm{x}$ \\
\hline & 2 & Coniochaeta ligniaria $2 \mathrm{w} 1 \mathrm{~F} 18 \mathrm{~S}$ ribosomal RNA gene & $91 \%$ & $99 \%$ & KF285992.1 & $\mathrm{x}$ \\
\hline & 3 & Coniochaeta ligniaria $2 \mathrm{w} 1 \mathrm{~F} 18 \mathrm{~S}$ ribosomal RNA gene & $91 \%$ & $99 \%$ & KF285992.1 & $\mathrm{x}$ \\
\hline & 4 & Acremonium sp. 11665 DLW-2010 18S ribosomal RNA gene & $98 \%$ & $96 \%$ & GQ867783.1 & $\mathrm{x}$ \\
\hline \multirow[t]{3}{*}{ WS2 } & 5 & Coniochaeta ligniaria $2 \mathrm{w} 1 \mathrm{~F} 18 \mathrm{~S}$ ribosomal RNA gene & $92 \%$ & $99 \%$ & KF285992.1 & $\mathrm{x}$ \\
\hline & 6 & Acremonium sp. 11665 DLW-2010 18S ribosomal RNA gene & $98 \%$ & $96 \%$ & GQ867783.1 & $\mathrm{x}$ \\
\hline & 7 & Acremonium sp. 11665 DLW-2010 18S ribosomal RNA gene & $99 \%$ & $97 \%$ & GQ867783.1 & $\mathrm{x}$ \\
\hline \multirow[t]{3}{*}{ SG } & 8 & Coniochaeta ligniaria 2 t2.1 F 18 S ribosomal RNA gene & $94 \%$ & $96 \%$ & KF285995.1 & $\mathrm{x}$ \\
\hline & 9 & Coniochaeta ligniaria $2 \mathrm{w} 1 \mathrm{~F} 18 \mathrm{~S}$ ribosomal RNA gene & $95 \%$ & $99 \%$ & KF285992.1 & $\mathrm{x}$ \\
\hline & 10 & Acremonium sp. 11665 DLW-2010 18S ribosomal RNA gene & $98 \%$ & $95 \%$ & GQ867783.1 & $\mathrm{x}$ \\
\hline
\end{tabular}


Table 2 (continued)

\begin{tabular}{|c|c|c|c|c|c|c|}
\hline $\mathrm{T}$ & Isol & Identification & $\mathrm{Cov}$ & Ident & Access no. & Enz act \\
\hline \multirow[t]{3}{*}{$\mathrm{CS}$} & 11 & Coniochaeta ligniaria $2 \mathrm{w} 1 \mathrm{~F} 18 \mathrm{~S}$ ribosomal RNA gene & $94 \%$ & $97 \%$ & KF285992.1 & $\mathrm{x}$ \\
\hline & 12 & Acremonium sp. 11665 DLW-2010 18S ribosomal RNA gene & $95 \%$ & $96 \%$ & GQ867783.1 & $\mathrm{x}$ \\
\hline & 13 & Acremonium sp. 11665 DLW-2010 18S ribosomal RNA gene & $98 \%$ & $97 \%$ & GQ867783.1 & $\mathrm{x}$ \\
\hline
\end{tabular}

Abbreviations: WS1 - wheat straw pH 7.2, WS2 - wheat straw pH 9.0, SG - switchgrass $\mathrm{pH} 7.2, C S$ - corn stover $\mathrm{pH}$ 7.2, T - treatment, Isol - isolate, Cov - coverage, Ident - identity, Access No. - access number, Enz.Act - enzymatic activity

\section{Bacterial and Fungal (Hemi)cellulolytic Activities}

In the light of their presumed dominance in the PCR-DGGE profiles, we tested the microorganisms affiliated with $S$. kitahiroshimense, E. amnigenus, $R$. terrigena, $P$. putida and $S$. rhizophila, next to P. xylanexedens, for their ability to deconstruct plant biomass. We thus tested (hemi)cellulolytic activity for these, next to other isolates (CMC-ase and xylanase). Twenty one bacterial strains derived from treatments WS1 (5/11), WS2 (6/8), SG (5/9), and CS (5/8), respectively, showed positive CMC-ase as well as xylanase activities. Indeed, the strains affiliated with Sphingobacterium kitahiroshimense, $R$. terrigena, $P$. vranovensis, $S$. rhizophila (bacteria), C. lignaria, and Acremonium sp. (fungi), presumably belonging to the microbial "cores", showed positive

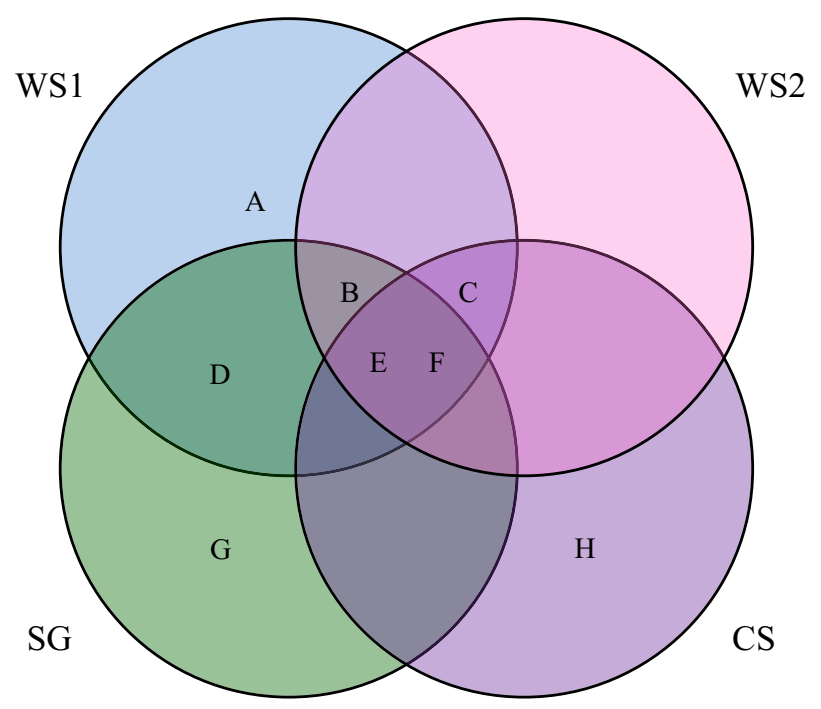

A: Klebsiella (Gammaproteobacteria)

B: Raoultella (Gammaproteobacteria)

C: Stenotrophomonas; Pseudomonas (Gammaproteobacteria)

D: Enterobacter (Gammaproteobacteria)

E: Sphingobacterium (Bactereoides); Coniochaeta

F: Acremonium

G: Delftia (Betaproteobacteria); Paenibacillus (Firmicutes)

H: Sanguibacter (Actinobacteria); Comamonas (Betaproteobacteria)

Fig. 6 Venn diagram indicating unique and common bacterial and fungal strains across all treatments. Abbreviations: WS1 - wheat straw $\mathrm{pH} 7.2$, WS2 - wheat straw $\mathrm{pH} 9.0, S G$ - switchgrass $\mathrm{pH} 7.2, C S$ - corn stover $\mathrm{pH} 7.2$ (hemi)cellulolytic activity. In addition, specialist isolates (P. xylanexedens, S. inulus, and C. jiangduensis) also showed CMC-ase and xylanase activity (Table 2 and Supplementary Fig. S2c; S2d).

\section{Discussion}

The development of efficient microbial consortia to deconstruct plant biomass is of great industrial interest. The biodegradation process involves a network of enzymatic transformations that requires timely production by microbial cells and extracellular availability. Moreover, stress conditions might be better endured by consortia than by single strains as a result of community interactions. In this study, different plant biomass sources were used to produce specific microbial consortia for lignocellulose degradation. The dilution-to-stimulation approach used worked well, as verified by observing the growth of bacterial cells in each step, which reached up to $\sim 10^{8}$ cells $\mathrm{mL}^{-1}$ after 5 to 6 days of incubation. Previous work from our lab [18] — using a similar approach to enrich lignocellulose degraders - observed that maximal cell densities of $10^{7}-10^{8}$ cells $\mathrm{mL}^{-1}$ were reached after 6 to 8 days. However, lower temperatures and shaking conditions were used than the ones used in this study (i.e., $25^{\circ} \mathrm{C}$ and $100 \mathrm{rpm}$ ). Consistent with Jimenez et al. [18], the fungal communities did not build up high densities in the enrichment systems (Fig. 1b), with ITS1 gene copy numbers remaining well below the bacterial $16 \mathrm{~S}$ rRNA gene copy numbers.

On all substrates, the microbial consortia, across all treatments, effected enhanced substrate weight loss from transfers 6 to 9 , with values ranging from a minimum of about $36 \%$ (WS2, in transfer 6) up to around $48 \%$ (CS, in transfer 9). In addition, treatments SG and CS had higher values of substrate weight loss than treatments WS1 and WS2 (Fig. 2). Such weight loss data were roughly consistent with the overall FTIR-based data (Table 1). Thus, the plant biomass degradative microbial consortia were apparently "trained" to become more efficient in the degradation process over time. Xu et al. [41], testing the weight loss of corn stover in a culture of white rot fungus Irpex lacteus, described a substrate weight loss of $\sim 20 \%$ after 40 days of incubation. Similarly, Baldrian et al. 
[4] showed the weight loss of wheat straw during growth of Pleurotus ostreatus to be at the level of $\sim 30 \%$ after 20 days of incubation. Thus, in spite of the fact that we do not provide a side-by-side comparison, we conclude that mixed microbial consortia (i.e., consisting of both bacterial and fungal partners) have potentially higher biodegradative performance than single-isolate cultures.

The FTIR-based analyses showed treatment SG to have the highest lignin degradation rate (ca. $39 \%$ ), while the highest rates for cellulose and hemicellulose were obtained in the WS1 (ca. $52 \%$ ) and CS (ca. $63 \%$ ) treatments, respectively (Fig. 3). Whereas several previous studies have addressed plant biomass degradation by breeding different microbial consortia [5, 17, 18, 44], none has studied the influence of different lignocellulose substrates or different $\mathrm{pH}$ conditions as factors driving the enrichment of specific microbial consortia once the same microbial source is used as an inoculum. Here, we clearly show that substrate type, next to $\mathrm{pH}$ (for treatments using WS), are major driver of the microbial consortia that are bred from one source inoculum. Such consortia were consistent across replicates yet were found to be composed of different members across treatments (Fig. 5 (a)). Given the fact that the lignocellulose compositions of the three used substrates were roughly similar (Table 1) and taking on board the evidence that the rates of decomposition of these different compounds were different across the treatments (Table 1), we can discern a scientific basis for the divergent microbial consortia emerging in the different substrates. These lie either or both in the presumed differences in soluble carbohydrate and sugar compositions or in the intricate bonds and/or branching within and between the three substrates that make up the lignocellulose moieties of the three plants. However, with respect to the bacterial parts of the consortia, we detected a restricted "core" consortium across the treatments, next to a treatment-specific one. The apparent "core" was consistently composed of organisms affiliated with Sphingobacterium kitahiroshimense, Raoultella terrigena, Pseudomonas putida and Stenotrophomonas rhizophila. Interestingly, these genera were also found to become abundant in previously-bred microbial consortia using (un)treated wheat straw as the carbon source [18]. Presumably, these consist of "generalists" that grow upon common target in the diverse plant biomasses.

Moreover, the fungal consortia also revealed stable structures that were different from each other across the treatments. On top of that, treatments WS1 and WS2 revealed the emergence of statistically similar fungal community structures (Fig. 5 (b)), indicating a general lack of effect of $\mathrm{pH}$ conditions on these communities, in this case specifically for the WS treatment. We cannot easily explain this fact, as Jiménez et al. [18] noticed that fungal community structures enriched with wheat straw and torrified wheat straw were very dissimilar from each other.
Furthermore, a suite of highly active isolates that likely represent members of the core microbiota was obtained, and their analysis yielded important observations. First, as activity detection included the observation of haloes, the produced enzymes were externally secreted by the cells. Secretion is a critical, yet overlooked, bottleneck in studies that aim at the establishment of efficient microbial degrader consortia. Our Raoultella and Klebsiella isolates (Enterobacteriales) showed extracellular (xylanolytic/cellulolytic) activities, suggesting that these bacteria have metabolic roles in plant polymer degradation. This finding is possibly congruent with studies that showed members of the Enterobacteriales abound in insect herbivore microbiomes [3, 35].

The finding of Stenotrophomonas - like organisms (part of the core consortia) showing (hemi)cellulolytic activity-corroborates data obtained by Qi et al. [32]. The latter study on lignocellulosic substrate bioconversion by yellow mealworm gut microbiomes produced a degrading microbial consortium that contained key Stenotrophomonas strains for the degradation of lignocellulosic material.

Interestingly, bacterial strains retrieved from CS (affiliated with Comamonas and Sanguibacter) and SG (affiliated with Paenibacillus) also showed degrader activities, suggesting these are potentially active lignocellulose degraders. Wang et al. [45] reported organisms affiliated with Paenibacillus to be key degraders of lignocellulosic substrates (from reeds), whereas Cook et al. [7] found Sanguibacter suarezii to degrade CMC, starch, methylumbelliferyl (MUF)-xylopyranoside, MUF-arabinofuranoside and MUF-glucopyranoside. Finally, it is noteworthy that Coniochaeta - and Acremoniumlike fungi with $\mathrm{CMC}$-ase and xylanase activities, were consistently found across all treatments. Thus, such organisms might have key roles in the core degradative consortium. The genus Coniochaeta encompasses filamentous fungi that are active in the degradation of decaying wood in soil and are probably involved in hemicellulose degradation [26]. Recently, Plectosphaerella (which is highly related to Acremonium) has been reported to utilize xylose and CMC, yielding lipids $[24,36]$. Thus, the production of lipids by such organismsusing lignocellulose as a substrate - may constitute a metabolic pathway to be explored in order to yield oil-rich compounds - a process with high economic competitiveness [25].

In summary, we developed four lignocellulosedegrading microbial consortia from forest soil using three different plant substrates. Substrate type was found to be the major driver of the composition of the bacterial and fungal communities in the final consortia, as evidenced by PCR-DGGE community profiling along the enrichments. Moreover, a common core consortium of low richness was detected. Further understanding of the biotic interactions in the bred consortia will pave the way for the establishment of an efficient multispeciesbased process for lignocellulose degradation. 
Acknowledgments We thank Francisco Dini-Andreote for critical reading of the manuscript. This work was supported by Coordination for the Improvement of Higher Education Personnel (CAPES-Brazil) and the BE-Basic partner organizations (the Netherlands).

Open Access This article is distributed under the terms of the Creative Commons Attribution 4.0 International License (http:// creativecommons.org/licenses/by/4.0/), which permits unrestricted use, distribution, and reproduction in any medium, provided you give appropriate credit to the original author(s) and the source, provide a link to the Creative Commons license, and indicate if changes were made.

\section{References}

1. Adapa PK, Tabil LG, Schoenau GJ, Canam T, Dumonceaux T (2001) Quantitative analysis of lignocellulosic components of non-treated and steam exploded barley, canola, oat and wheat straw using fourier transform infrared spectroscopy. J Agric Sci Technol 1:177-188

2. Amarasekara AS (2014) Handbook of cellulosic ethanol. WileyScrivener.

3. Aylward FO, Burnum KE, Scott JJ, Suen G, Tringe SG, Adams SM, Barry KW, Nicora CD, Piehowski PD, Purvine SO, Starrett GJ, Goodwin LA, Smith RD, Lipton MS, Currie CR (2012) Metagenomic and metaproteomic insights into bacterial communities in leaf-cutter ant fungus gardens. ISME J 6:1688-1701. doi:10. 1038/ismej.2012.10

4. Baldrian P, Gabriel J (2003) Lignocellulose degradation by Pleurotus ostreatus in the presence of cadmium. FEMS Microbiol Lett 220:235-240. doi:10.1016/S0378-1097(03)00102-2

5. Chen LZ, Zhang HF, Ryu DD, Bao J (2009) Screening of oleaginous yeast strains tolerant to lignocellulose degradation compounds. Appl Biochem Biotechnol 159:591-604. doi:10.1007/ s12010-008-8491-x

6. Christian DG, Riche AB, Yates NE (2002) The yield and composition of switchgrass and coastal panic grass grown as a biofuel in southern England. Bioresource Technol 83:115-124. doi:10.1016/ S0960-8524(01)00201-2

7. Cook DM, Henriksen ED, Upchurch R, Peterson JBD (2007) Isolation of polymer-degrading bacteria and characterization of the hindgut bacterial community from the detritus-feeding larvae of Tipula abdominalis (Diptera: Tipulidae). Appl Environ Microbiol 73:5683-5686. doi:10.1128/AEM.00213-07

8. DeAngelis KM, D'Haeseleer P, Chivian D, Fortney JL, Khudyakov J, Simmons B, Woo H, Arkin AP, Davenport KW, Goodwin L, Chen A, Ivanova N, Kyrpides NC, Mavromatis K, Woyke T, Hazen TC (2011) Complete genome sequence of "Enterobacter lignolyticus" SCF1. Stand Genomic Sci 5:69-85. doi:10.4056/ sigs. 2104875

9. Dhanoa MS, Lister SJ, Sanderson R, Barnes RJ (1994) The link between multiplicative scatter correction (MSC) and standard normal variate (SNV) transformations of NIR spectra. J Near Infrared Spec 2:43-47. doi:10.1255/jnirs.30

10. Demain AL, Newcomb M, Wu JHD (2005) Cellulase, clostridia, and ethanol. Microbiol Mol Biol Rev 69:124-154. doi:10.1128/ MMBR.69.1.124-154.2005

11. Du R, Yan J, Li S, Zhang L, Zhang S, Li J, Zhao G, Qi P (2015) Cellulosic ethanol production by natural bacterial consortia is enhanced by Pseudoxanthomonas taiwanensis. Biotechnology for Biofuels 8:10. doi:10.1186/s13068-014-0186-7

12. FitzPatrick M, Champagne P, Cunningham MF (2012) Quantitative determination of cellulose dissolved in 1-ethyl-3-methylimidazolium acetate using partial least squares regression on FTIR spectra. Carbohydr Polym 87:1124-1130. doi:10.1016/j.carbpol.2011.08.086

13. Flores-Mireles AL, Winans SC, Holguin G (2007) Molecular characterization of diazotrophic and denitrifying bacteria associated with mangrove roots. Appl Environ Microbiol 73:7308-7321. doi:10.1128/AEM.01892-06

14. Hamelinck CN, Hooijdonk GV, Faaij AP (2005) Ethanol from lignocellulosic biomass: techno-economic performance in short-, middle-, and long-term. Biomass Bioenerg 28:384-410. doi:10.1016/j. biombioe.2004.09.002

15. Hames BR, Thomas SR, Sluiter AD, Roth CJ, Templeton DW (2003) Rapid biomass analysis. new tools for compositional analysis of corn stover feedstocks and process intermediates ethanol production. Appl Biochem Biotechnol 105:5-16. doi:10.1007/ 978-1-4612-0057-4

16. Ho KL, Lee DJ, Su A, Chang JS (2012) Biohydrogen from cellulosic feedstock: dilution-to-stimulation approach. Int J Hydrogen Energy 37:15582-15587. doi:10.1016/j.ijhydene.2012.01.093

17. Hui W, Jiajia L, Yucai L, Peng G, Xiaofen W, Kazuhiro M, Zongjun C (2013) Bioconversion of un-pretreated lignocellulosic materials by a microbial consortium XDC-2. Bioresour Technol 136:481487. doi:10.1016/j.biortech.2013.03.015

18. Jiménez DJ, Korenblum E, van Elsas JD (2014) Novel multispecies microbial consortia involved in lignocellulose and 5hydroxymethylfurfural bioconversion. Appl Microbiol Biotechnol 98:2789-2803. doi:10.1007/s00253-013-5253-7

19. Kasana RC, Salwan R, Dhar H, Dutt S, Gulati A (2008) A rapid and easy method for the detection of microbial cellulases on agar plates using gram's iodine. Curr Microbiol 57:503-507. doi:10.1007/ s00284- 008-9276-8

20. Kim T, Lee Y, Sunwoo C, Kim J (2006) Pretreatment of corn stover by low-liquid ammonia recycle percolation process. Appl Biochem Biotechnol 133:41-57. doi:10.1007/s12010-009-8524-0

21. Koullas DP, Christakopoulos P, Kekos D, Macris BJ, Koukios EG (1992) Correlating the effect of pretreatment on the enzymatic hydrolysis of straw. Biotechnol Bioeng 39:113-116. doi:10.1002/bit. 260390116

22. Krasznai DJ, Champagne P, Cunningham MF (2011) Quantitative characterization of lignocellulosic biomass using surrogate mixtures and multivariate techniques. Bioresour Technol 110:652661. doi:10.1016/j.biortech.2012.01.089

23. Lee DJ, Show KY, Wang A (2013) Unconventional approaches to isolation and enrichment of functional microbial consortium-a review. Bioresour Technol 136:697-706. doi:10.1016/j.biortech. 2013.02. 075

24. Li SH, Lin Q, Li XR, Xu H, Yang YX, Qiao DR, Cao Y (2012) Biodiversity of the oleaginous microorganisms in Tibetan Plateau. Braz J Microbiol 43:627-634. doi:10.1590/S151783822012000200026

25. Liu Z, Gao Y, Chen J, Imanaka T, Bao J, Hua Q (2013) Analysis of metabolic fluxes for better understanding of mechanisms related to lipid accumulation in oleaginous yeast Trichosporon cutaneum. Bioresour Technol 130:144-151. doi:10.1016/j.biortech.2012.12. 072

26. López MJ, Vargas-Garcia MC, Suarez-Estrella F, Nichols NN, Dien BS, Moreno J (2007) Lignocellulose-degrading enzymes produced by the ascomycete Coniochaeta ligniaria and related species: application for a lignocellulosic substrate treatment. Enzyme Microb Technol 40:794-800. doi:10.1016/j.enzmictec.2006.06.012

27. Lu YT, Chen XB, Zhou P, Li ZH (2005) Screening on oildecomposing microorganisms and application in organic waste treatment machine. J Environ Sci 17:440-444

28. Lynd LR, Weimer PJ, van Zyl WH, Pretorius IS (2002) Microbial cellulose utilization: fundamentals and biotechnology. Microbiol Mol Biol Rev 66:506-577. doi:10.1128/MMBR.66.3.506-577.2002 
29. Mabee WE, Gregg DJ, Saddler JN (2005) Assessing the emerging biorefinery sector in Canada. Appl. Biochem Biotechnol 123:765778. doi:10.1385/ABAB:123:1-3:0765

30. Mani S, Tabil LG, Sokhansanj S (2006) Effects of compressive force, particle size and moisture content on mechanical properties of biomass pellets from grasses. Biomass Bioenerg 30:648-654. doi:10.1016/j.biombioe.2005.01.004

31. Pereira e Silva MC, Dias AC, van Elsas JD, Salles JF (2012) Spatial and temporal variation of archaeal, bacterial and fungal communities in agricultural soils. PLoS ONE 7:e51554. doi:10.1371/journal. pone. 0051554

32. Qi W, Chen CL, Wang JY (2011) Reducing sugar-producing bacteria from guts of Tenebrio molitor Linnaeus (Yellow mealworm) for lignocellulosic waste minimization. Microbes Environ 26:354 359. doi:10.1264/jsme2.ME11129

33. Savitzky A, Golay MJE (1964) Smoothing and differentiation of data by simplified least squares procedures. Anal Chem 36:16271639. doi:10.1021/ac60214a047

34. Schwarz WH (2001) The cellulosome and cellulose degradation by anaerobic bacteria. Appl Microbiol Biotechnol 56:634-649. doi:10. 1007/s002530100710

35. Suen G, Scott JJ, Aylward FO, Adams SM, Tringe SG, Pinto-Tomás AA, Foster CE, Pauly M, Weimer PJ, Barry KW, Goodwin LA, Bouffard P, Li L, Osterberger J, Harkins TT, Slater SC, Donohue TJ, Currie CR (2010) An insect herbivore microbiome with high plant biomass-degrading capacity. PLoS Genet 6, e1001129

36. Summerbell RC, Gueidan C, Schroers HJ, de Hoog GS, Starink M, Rosete YA, Guarro J, Scott JA (2011) Acremonium phylogenetic overview and revision of Gliomastix, Sarocladium, and Trichothecium. Stud Mycol 68:139-162. doi:10.3114/sim.2011.68.06
37. Sun XF, Sun RC, Fowler P, Baird MS (2005) Extraction and characterization of original lignin and hemicelluloses from wheat straw. J Agr Food Chem 53:860-870. doi:10.1021/jf040456q

38. Taketani RG, Franco NO, Rosado AS, van Elsas JD (2010) Microbial community response to a simulated hydrocarbon spill in mangrove sediments. J Microbiol 48:7-15. doi:10.1007/ s12275-009-0147-1

39. U.S. Department of Energy (2006) Biomass feedstock composition

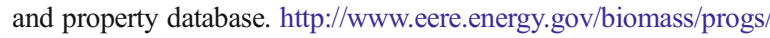
search1.cgi. Accessed October 2015.

40. Wong KK, Tan LU, Saddler JN (1988) Multiplicity of beta-1,4xylanase in microorganisms: functions and applications. Microbiol Rev 52(3):305-317

41. Xu C, Ma F, Zhang X (2009) Lignocellulose degradation and enzyme production by Irpex lacteus CD2 during solid-state fermentation of corn stover. J Biosci Bioeng 108:372-375. doi:10.1016/j. jbiosc.2009.04.023

42. Zhang YHP, Lynd LR (2004) Toward an aggregated understanding of enzymatic hydrolysis of cellulose: noncomplexed cellulase systems. Biotechnol Bioeng 88:797-824. doi:10.1002/bit.20282

43. Zuroff TR, Curtis WR (2012) Developing symbiotic consortia for lignocellulosic biofuel production. Appl Microbiol Biotechnol 93: 1423-1435. doi:10.1007/s00253-011-3762-9

44. Wang XJ, Yuan XF, Wang H, Li J, Wang XF, Cui ZJ (2011) Characteristics and community diversity of a wheat strawcolonizing microbial community. Afr J Biotechnol 10:7853-7861. doi:10.5897/ AJB11.276

45. Wang Y, Liu Q, Yan L, Gao Y, Wang Y, Wang W (2013) A novel lignin degradation bacterial consortium for efficient pulping. Bioresource Technol 139:113-119. doi:10.1016/j.biortech.2013. 04.033 